\title{
Depositional Facies and Sequence Stratigraphic Study in Parts of Benin (Dahomey) Basin SW Nigeria: Implications on the Re-Interpretation of Tertiary Sedimentary Successions
}

\author{
Solomon 0. Olabode1, Muraina Z. Mohammed ${ }^{2}$ \\ ${ }^{1}$ Department of Applied Geology, The Federal University of Technology, Akure, Nigeria \\ ${ }^{2}$ Department of Earth Sciences, Adekunle Ajasin University, Akungba-Akoko, Nigeria \\ Email: soolabode@futa.edu.ng, bodesolomon@yahoo.com,drmmohammed@yahoo.com
}

Received 11 January 2016; accepted 26 February 2016; published 29 February 2016

Copyright (C) 2016 by authors and Scientific Research Publishing Inc.

This work is licensed under the Creative Commons Attribution International License (CC BY). http://creativecommons.org/licenses/by/4.0/

(c) $\underset{\mathrm{EY}}{\mathrm{EP}}$ Open Access

\begin{abstract}
Detailed fieldwork in parts of the Benin (Dahomey) Basin SW, Nigeria has allowed the recognition of sedimentary successions deposited in different continental depositional environments interpreted as fluvial sedimentation characterised by abandoned channels and subaerial exposure features. The lithofacies recognised are: conglomerates, debris flow deposits, very coarse grained sandstone, ferruginous cross bedded sandstone, siltstone, shale/clay and massive sand. The lithofacies were interpreted in terms of sequence stratigraphic elements with the recognition of sequence boundaries characterised by distinct facies dislocations and subaerial exposures. Four depositional sequences (DS I to DS IV) were identified. Depositional sequences (DS I) exhibited a complete regressive-transgressive cycle comprising LST, TST and HST, while DS II to DS IV were incomplete comprising of sediments interpreted as LST deposits. On the basis of the depositional facies and sequence stratigraphic elements, the sediments in the area of study are interpreted as predominantly of Ilaro Formation while fewer exposures are sediments of the Coastal Plain Sands/ Benin Formation. This observation suggests a re-interpretation of the Tertiary sedimentary successions, which hitherto recognised all the sediments in the area of study as Coastal Plain Sands.
\end{abstract}

\section{Keywords}

Depositional Facies, Sequence Stratigraphy, Benin (Dahomey) Basin, Ilaro Formation, Coastal Plain Sands/Benin Formation 


\section{Introduction}

The Benin (Dahomey) Basin is one of the sedimentary basins located in the Gulf of Guinea oil province and straddles through four major countries, namely, Ghana, the Republic of Benin, The Federal Republic of Nigeria and the Republic of Togo (Figure 1). Other basins located in the Gulf of Guinea are Ivory Coast, Tano, Saltpond, Central and Keta (Figure 1). In the Nigerian sector of the basin, rocks of both Cretaceous and Tertiary ages are exposed along the major road sections and quarries (Figure 2). Attempts have been made by previous workers to study the Nigerian sector, what has become increasingly evident over the past years is that the Nigerian sector of the Benin (Dahomey) Basin is little understood, especially when this basin is compared with its contiguous Niger Delta Basin.

The exposed sedimentary successions in the Nigerian sector of the Benin basin has been studied and presented in some published works [1] [2], none of these papers have specifically applied the concept of sequence stratigraphy to decipher the sedimentary successions. Therefore, this paper is aimed at presenting new sets of data on newly exposed outcrops in some parts of the Benin Basin. The sedimentological characteristics of the exposed sedimentary successions are described and analysed together with their depositional facies. These depositional facies are related to their sequence stratigraphic elements with a view to re-interpreting the Tertiary sedimentary successions in the area of study. It is intended that the results obtained shall give a new insights into the depositional facies, sequence stratigraphic elements and their relationship to the Tertiary formations in the area of study.

\section{Geological Setting and Stratigraphy}

The Nigerian sector of the Benin (Dahomey) Basin is located in the southwestern Nigeria covering three different states, namely, Lagos, Ogun and Ondo (Figure 3). In these three states the Benin Basin covers both the onshore and offshore parts. The onshore part includes the areas where both the Cretaceous and Tertiary sedimentary rocks are exposed along road cuts and quarries. Detailed geology, evolution, stratigraphy and hydrocarbon occurrence of the basin are contained in publications by [1] [2] [4]-[9]. Most of these authors have recognized two structural elements, which comprise the Benin basin proper and the Okitipupa structure. [6] identified three geoblocks; namely, the onshore geoblock (Bodashe, Ileppa-Ojo geoblock), the Okitipupa structure (Union Gbekebo geoblock) and offshore geoblock. They emphasized that these three geoblocks have gone through three main stages of basin evolution. These stages are initial graben (pre-drift) phase, prolonged transitional stage and open marine (drift) phase. Early study on the basin stratigraphy by [1] recognized both Cretaceous and Tertiary

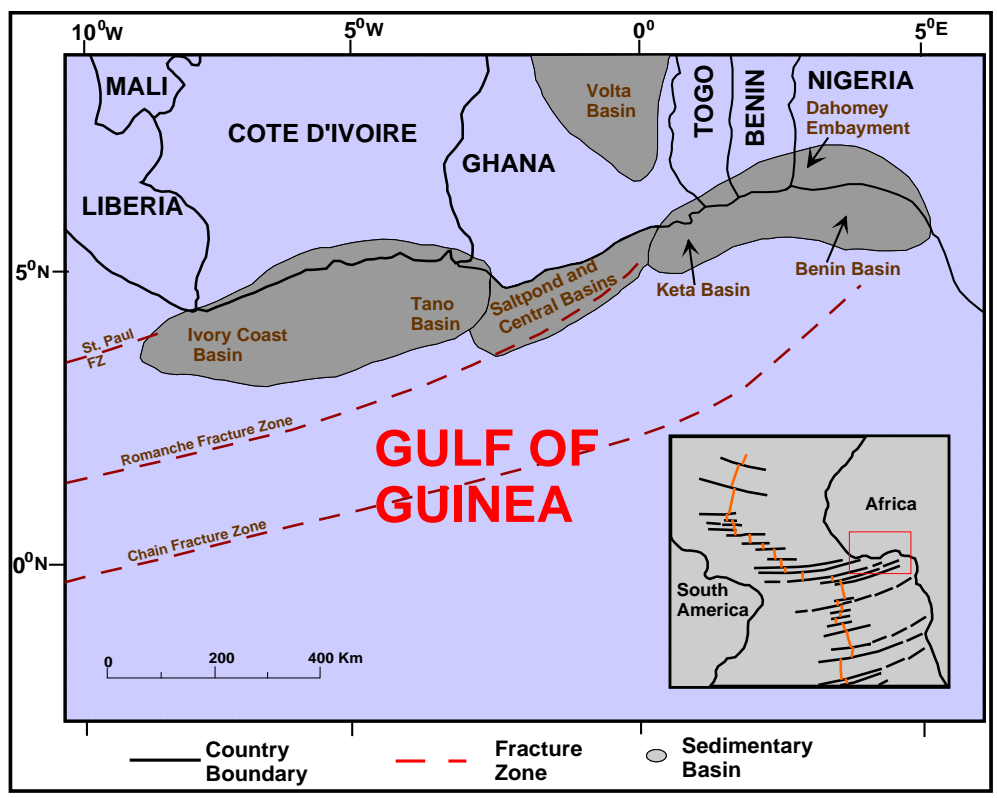

Figure 1. Regional map of the Gulf of Guinea showing the location of Benin (Dahomey) Basin in relation to other basins (modified after [3]). 


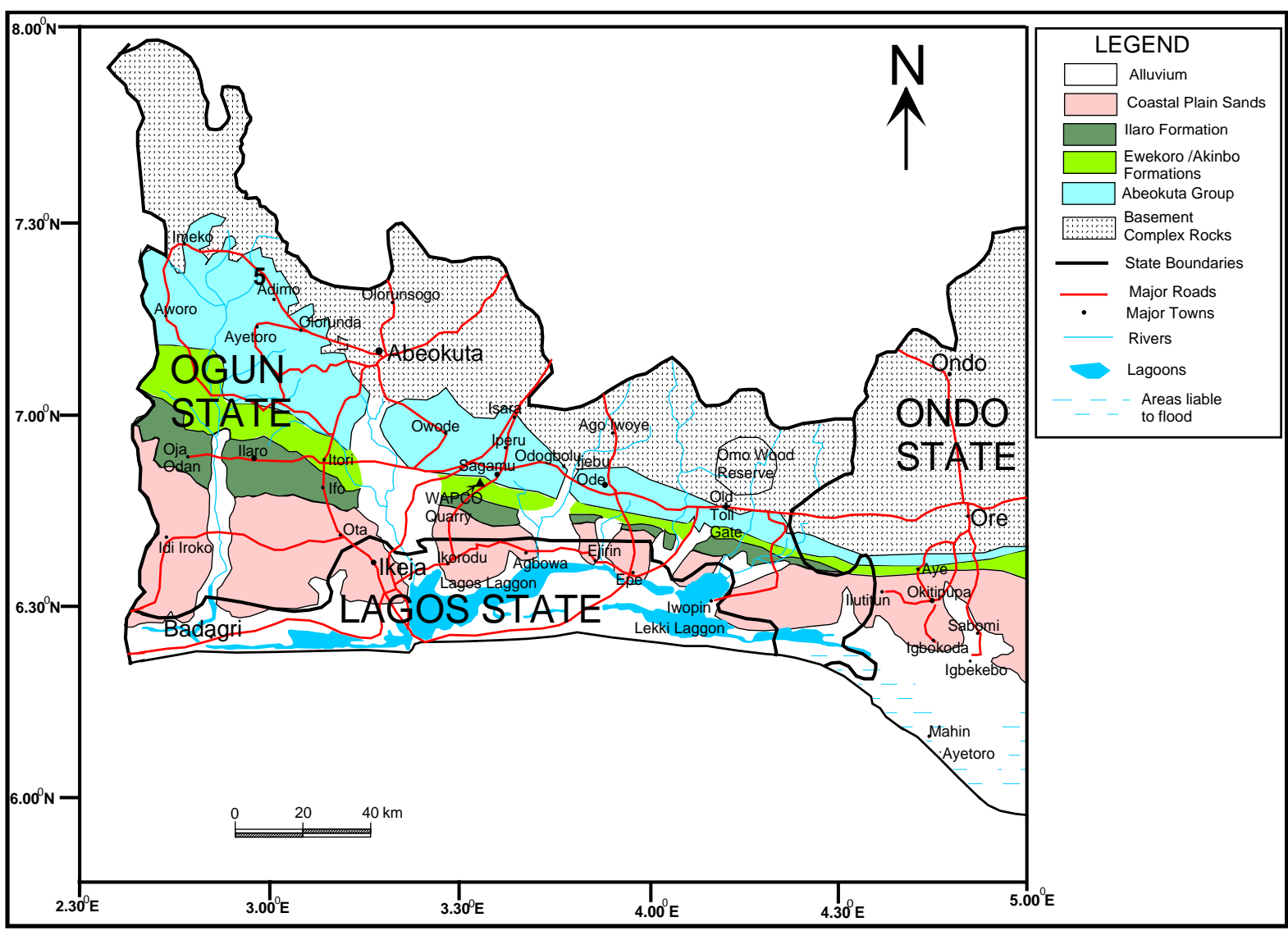

Figure 2. Geological map of Dahomey Basin in the Nigerian sector and the states located on the basin (modified after [1]).

sediments (Figure 3). Other subsequent workers recognized three chronostratigraphic units: 1) pre-lower Cretaceous folded sequence, 2) Cretaceous sequence and 3) Tertiary sequence [5] [8]. The Cretaceous stratigraphy as compiled from outcrop and borehole records consists Abeokuta Group sub-divided into three informal formational units namely Ise, Afowo, and Araromi [5]. Ise Formation unconformably overlies the basement complex and comprises coarse conglomeratic sediments. Afowo Formation is composed of transitional to marine sands and sandstone with variable but thick interbedded shales and siltstone. Araromi is the uppermost formation and is made up of shales and siltstone with interbeds of limestone and sands (Figure 3). The Tertiary sediments consist of Ewekoro, Akinbo, Oshosun, Ilaro and Benin (coastal plain sand) Formations. Ewekoro Formation is made up of fossiliferous well-bedded limestone while Akinbo and Oshosun Formations are made up of flaggy grey and black shales. Glauconitic rock bands and phosphatic beds define the boundary between Ewekoro and Akinbo Formations. Ilaro and Benin Formations are predominantly coarse sandy estuarine, deltaic and continental beds.

\section{Methods}

Fieldwork was conducted in parts of the Benin (Dahomey) Basin, which included reconnaissance and detailed measurements of stratigraphic sections. During the reconnaissance fieldwork, field visits were carried out along traverses, which include road cuts, quarries and dredging sites. Field measurements and description of lithologic sections were carried out using the standard field procedures in a sedimentary terrain [10]-[12]. Section measurements began with the recording of all pertinent information such as date, topographic location and weather conditions.

Delineation of depositional facies features began with detailed logging of sedimentary outcrop sections observed during the fieldwork. Lithology, grain size, sedimentary and biogenic structures, post depositional and syndepositional features, and paleocurrent data were recorded in each measured sections. Facies relationships 


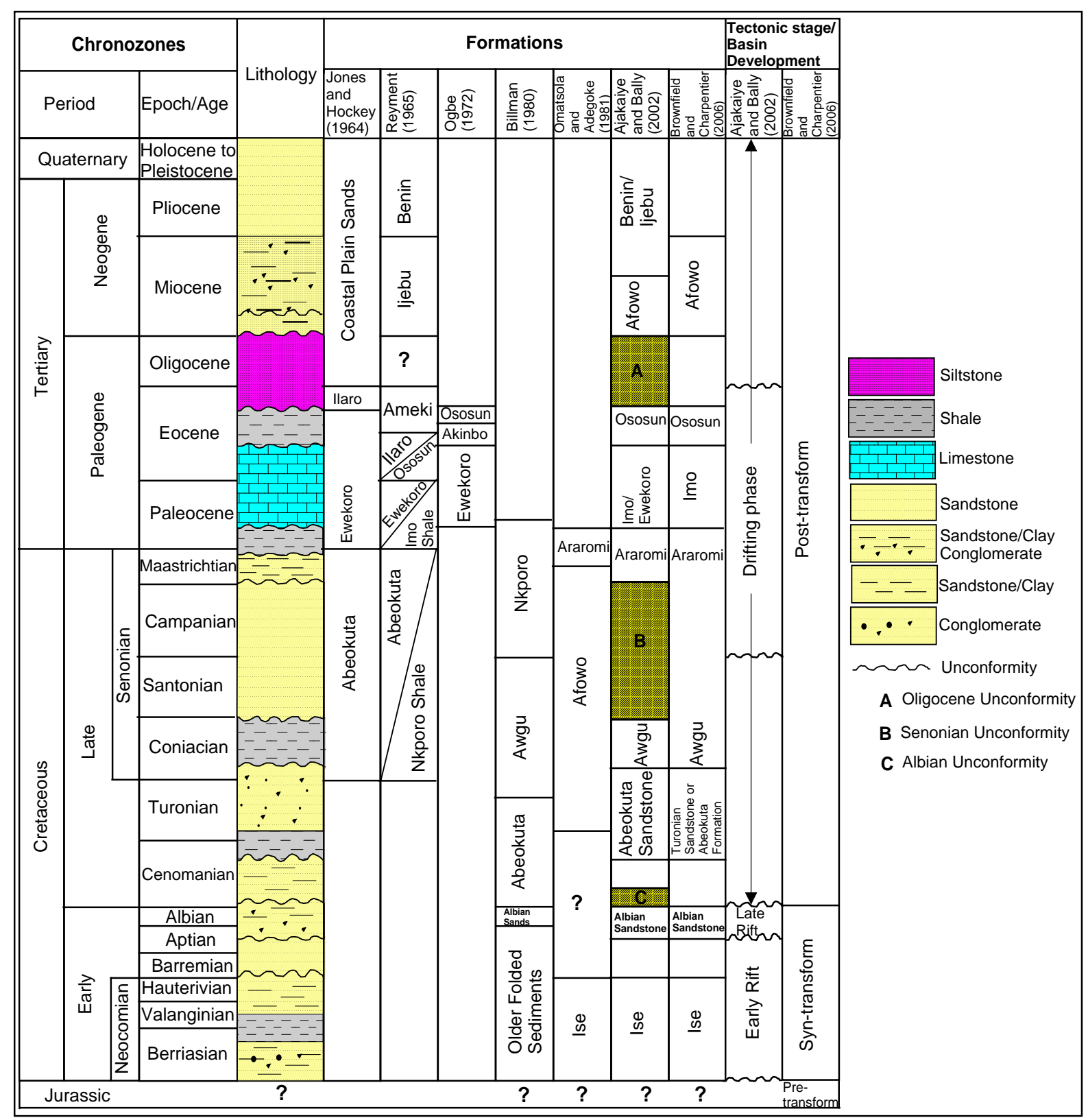

Figure 3. Generalised stratigraphic column showing age, lithology, and sequence of the formations and tectonic stage of basin development in the Nigerian sector of the Benin Basin.

were traced along the sedimentary sections using diagnostic criteria such as lithologic types, lithologic boundaries and erosional features. The recognition of sequence stratigraphic elements on outcrops in the study area began with the identification of sequence stratigraphic surfaces, because these surfaces form the boundaries used in the subdivision of the outcrops into sequence stratigraphic elements. Sequence delineation was based on the model which defined the sequence boundaries relative to the base level curve where a depositional sequence begins from one unconformity to the other or its correlative conformity [13]-[15].

Sequence stratigraphic surfaces were defined based on two criteria: 1) base level fall; and 2) base level rise [16]. Sub-aerial unconformities on the outcrops were recognized using the following: 1) surface of erosion or non-deposition created during base level fall by subaerial processes such as fluvial incision, sediment bypass and exposure features; 2) occurrence of facies dislocation where a proximal facies directly overlie deep water facies [17]; 3) occurrence of channel lag with the superposition of proximal on distal facies; 4) erosional trunca- 
tion; and 5) terminations on outcrops. The basic sequence elements identified are sequence stratigraphic surfaces and systems tracts. The resulting sequence stratigraphic interpretation was used to develop a model for the sequence stratigraphy of the rock exposures.

\section{Results}

\subsection{Lithofacies Descriptions and Interpretations}

On the basis of fieldwork carried out on the road sections and quarries/sand mining sites the outcrop sedimentary successions recognised in the area of study could be grouped into the following lithofacies; debris flow deposits, conglomerates, very coarse grained sand, ferruginous cross bedded sandstone, shale/clay and massive sand. These lithofacies are discussed in relation to the locations where they are encountered during the fieldwork.

\subsubsection{Ibonwon-Igbonla Locations}

Three main exposures were encountered in this area, the first two are road-cuts located after Augustine University with the following coordinates; $\mathrm{N}-06^{\circ} 39.183^{\prime}$; $\mathrm{E}-004^{\circ} 00.706^{\prime}$ and $\mathrm{N}-06^{\circ} 39.268^{\prime}$; $\mathrm{E}-004^{\circ} 01.294^{\prime}$. The second is a mining site located in Mafo before the bridge along Igbonla road with coordinate $\mathrm{N}-06^{\circ} 38.937^{\prime}$; $\mathrm{E}-004^{\circ} 01.524$. Five types of lithofacies encountered in these three exposures are clay, clayey sand, normal graded conglomerate debris deposit and massive sand (Figure 4).

Clay: The lithofacies is predominantly white, variegated in most exposures and contain other colours like yellow to brown-yellow, reddish brown and limonitic. It is slightly slippery and non-sticky. The lower boundary was not exposed in the mining site at Mafo where it was encountered. Field experience shows that this lithofacies is exposed in other traverses in the area of study (Figure 4).

Normal Graded Sands: This lithofacies was identified in one road-cut along this traverse where the lower part was not exposed. The thickness of the unit as observed in the road cuts is usually variable and comprises multistory upward fining sections, which vary from two to three. Thickness of each of the normally graded beds is between $90 \mathrm{~cm}$ and $1.6 \mathrm{~m}$. Generally, the normal graded sand exhibits similar textural characteristics. The base

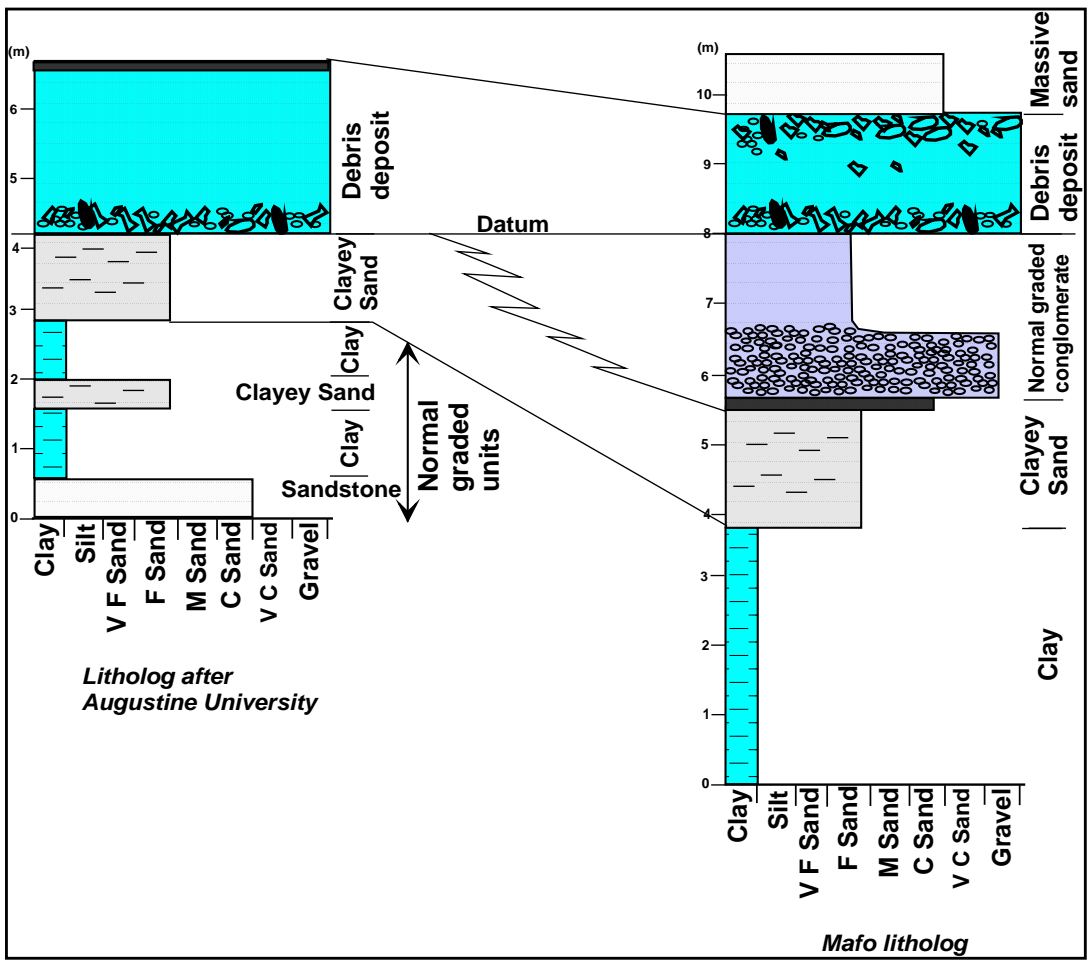

Figure 4. Lithology logs and lithofacies correlation of sedimentary successions along Igbonla-Ibonwon road. The lithologies exhibit lateral changes in facies and complete disappearance of the normal graded conglomerate in the exposures. 
is composed of coarse grained sand to clayey sand while the upper section contains clay. The sand colour is generally brown to light brown at the base, which changes gradually upward to reddish brown and yellowish. Sand is poorly sorted, angular to subangular and sharp. The clay is not laminated but is slippery, fairly sticky and milky white Sedimentary structures are difficult to recognize because of lateritisation, but crude horizontal laminations could be recognised. Contact between individual beds in the normally graded units varies from gradational to sharp (Figure 5).

Clayey sand: Clayey sand consists of brown to dark yellow medium to coarse grained sands that is slightly sticky. It is moderate to poorly sort and exhibits gradational contact with underlying clay. Quartz grains are angular to sub-angular while few are well rounded. The thickness of the lithofacies is variable but generally less than $3 \mathrm{~m}$. Sedimentary structures were not readily observed in the two exposures where the lithofacies was encountered in this traverse, this may not be unconnected with the high degree of weathering of the lithofacies. Occasionally, textural features are difficult to identify as a result of lateritisation (Figure 5 and Figure 6).

Normal Graded Oligomictic Orthoconglomerate: This lithofacies exhibits slightly mottled appearance, which is probably attributable to lateritisation that tends to obscure some of the inherent sedimentary structures. The lithofacies was observed at Mafo along Igbonla road where it lies directly on the clayey sand and is over $2.2 \mathrm{~m}$ thick. The normal graded oligomictic orthoconglomerate consists of a lower and an upper unit. The lower part is brown, dark brown, dark grey, brown and dirty white with mottled appearance. The matrix is made up of clayey sand and coarse sand. Clast is made up of pebble, rounded to well rounded and is predominantly made up of quartz/quartzite. Pebbles are usually in the millimeter scale, and the dimension of some pebbles measure up to 4 $\mathrm{cm}$ by $2.5 \mathrm{~cm}$. The matrix is subrounded to rounded, subdiscoidal to discoidal. It is typically massive with the absence of any noticeable sedimentary structures. The upper part is brown to dirty brown containing clayey sand. The lithofacies exhibit normal graded bedding while stratification was not feasible. Contact between the lower clayey sand and upper debris flow is sharp. The boundary with the underlying clayey sand is separated by a thin layer for ferruginous sandstone, which is less than $7 \mathrm{~cm}$ thick. Field experience revealed that this surface is characterised by polygonal cracks (mud cracks) as observed at the base of the conglomerate. The upper boundary

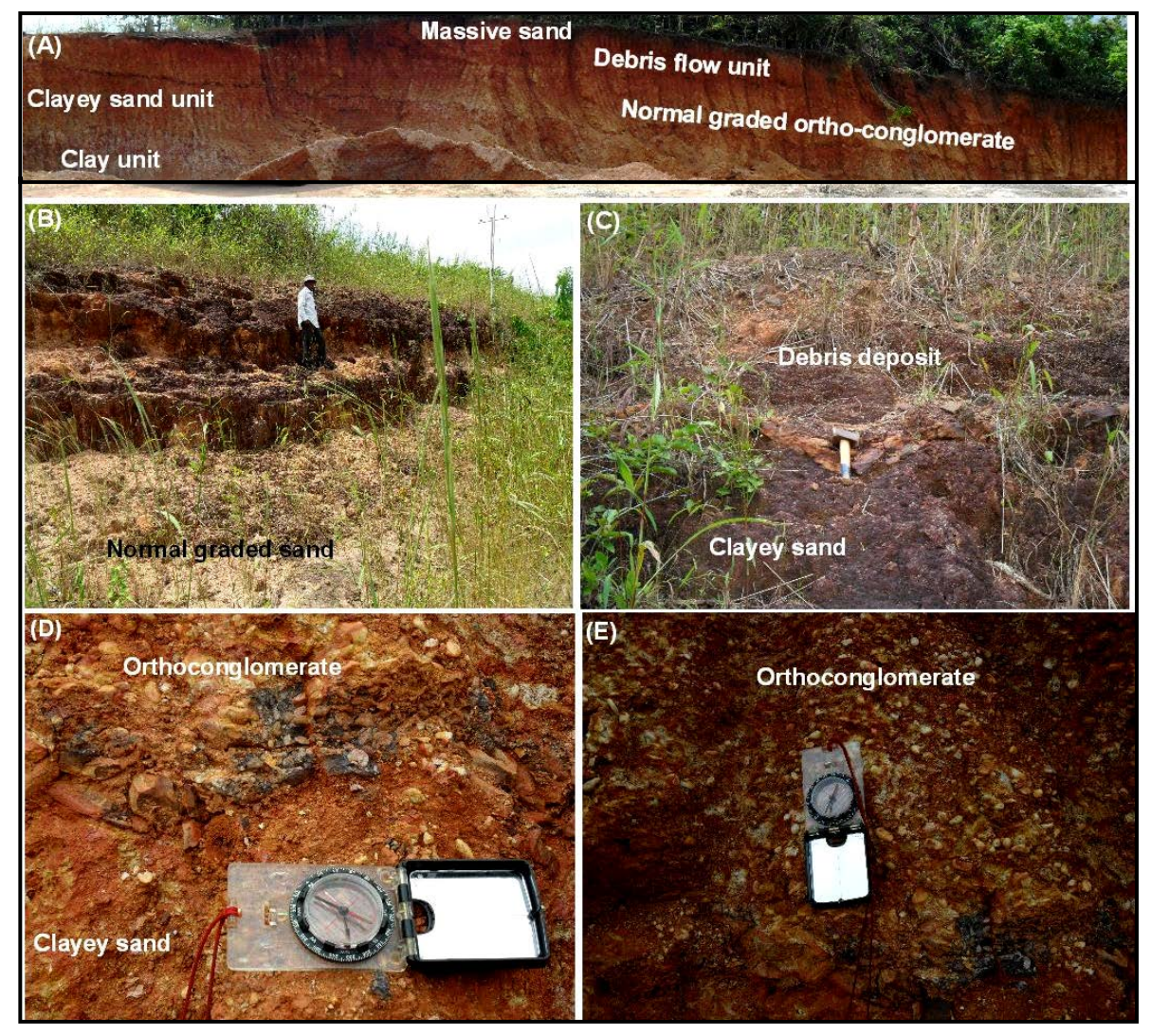

Figure 5. Field photographs of different lithofacies studied along Igbonla road. 


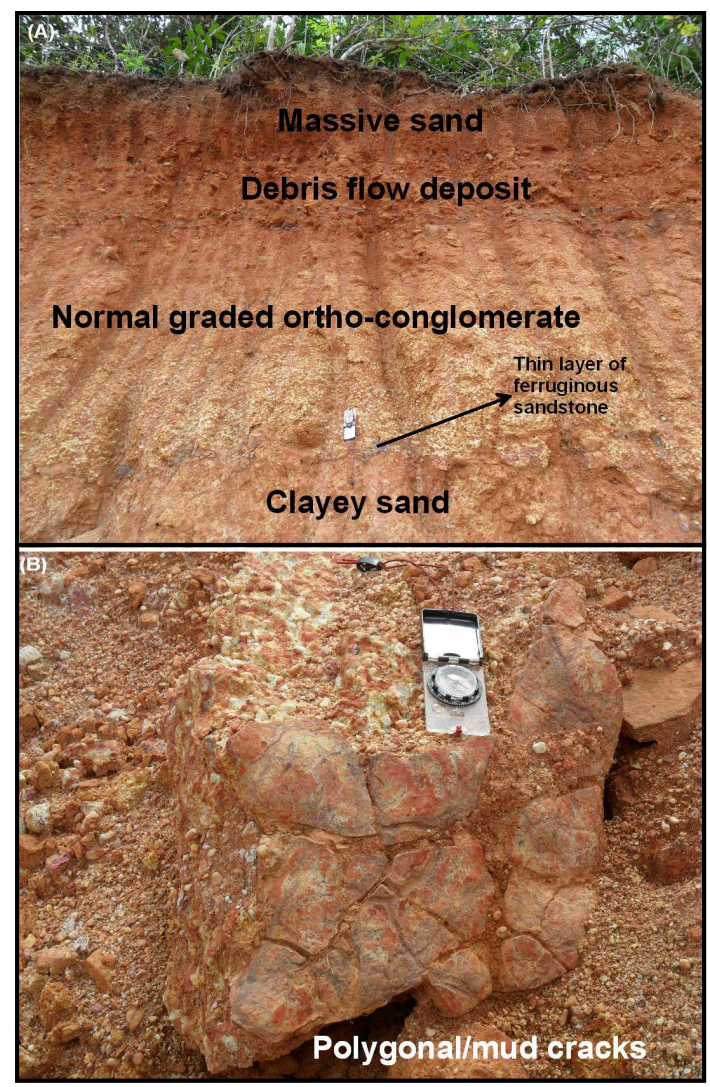

Figure 6. Field photographs of lithofacies and polygonal cracks as studied along Igbonla road.

with the debris flow deposits is also characterised by continuous thin layer consisting of boulders of ferruginous sandstone (Figure 5 and Figure 6).

Debris Flow Deposit (Diamictite?): Debris flow deposit regarded as diamictite occur at the upper part in the area of study. Usually it occurs as the topmost units or overlain by the massive sand in most of the exposures. This debris flow deposit was exposed at Mafo sand mining site and in the two exposures after Augustine University. In all these exposures the debris flow deposits are brown to reddish brown with dark patches. Generally they maintain a sharp but irregular contact with the lower and upper beds. The matrix is composed of poorly sorted, fine to very coarse quartz grains, while the clasts are heterogenous being made up of mudstone, siltstone and sandstone of various sizes. The clast is predominantly coble to boulder sized. Quartz grains of the matrix are angular to subangular, and subdiscoidal to discoidal. The large boulders exhibit different dimensions, but could be as large as $50 \mathrm{~cm}$ by $85 \mathrm{~cm}$. Field observations show that the layers containing the boulders of pre-existing sedimentary rock occur at the lower and upper boundaries of the debris flow deposits. The boulders are elongate to sub-elongate but occasionally they are rounded. The thicknesses of these layers vary from $10 \mathrm{~cm}$ to $30 \mathrm{~cm}$ (Figure 5 and Figure 6).

Massive Sand: This lithofacies occur as the topmost unit at the exposure observed in Mafo where it has been slightly lateritized. However, the distinct sharp boundary between the lithofacies and the underlying debris flow provides a good basis for differentiating the sand from the other ones. At this location the thickness is well above $1 \mathrm{~m}$. The sand is brown to light brown in colour, medium to coarse grained, subrounded to subangular, subdiscoidal to discoidal and poorly sorted. The upper boundary was not recognized but the lower boundary exhibits a sharp contact with the lithofacies below (Figure 6).

Interpretation: The vertical lithofacies successions from clay below through normal graded sands, clayey sand, debris flow deposits and capped by massive sand suggest facies associations in continental environments. These lithofacies are interpreted as products of fluvial deposition based upon the textural characteristics, vertical arrangement of the grain sizes and lithological associations. This interpretation is further supported by the 
occurrence of cycles of normally graded sandstone. The coarse grain sections probably represent traction deposits under high energy conditions while the vertical decrease in grain size records lower energy. The clay units within the lithofacies are interpreted as clay plugs filling abandoned channels or as overbank clays. This type of lithologic associations is consistent with meandering or braided river styles [18]. This interpretation agrees with the work of [19] who interpreted similar lithologic associations as fluvial deposits. However, one of the diagnostic distinguishing features of fluvial and braided deposits is the occurrence of larger fine-grained component of laminated clays in the former. Therefore the association of clays with these coarse grained multi-story sands, the absence of climbing ripple lamination, parallel lamination and small ripple cross bedding, which are characteristic sedimentary structures indicative of sedimentation by levee and crevasse splay deposits suggest that the deposits are of meandering fluvial systems. Similar sand bodies with upward fining trends, absence of mudstones and textural characteristics similar to those exhibited by the lithofacies have been interpreted as fluvial deposits [20].

The lower part of the conglomerates, especially at the contact between the clayey sand combined with the lack of sedimentary structures are suggestive of bed load, traction of gravels and channel lag deposits probabbly deposited by pseudoplastic debris flow deposits [11] [21]. Normal graded conglomerate can be deposited by longitidinal bars that developed by means of vertical and lateral growth of horizontally stratified gravel sheets or by high energy sream flow processes within coarse grained, shallow and low-sinuosity braided channels. The high degree of roundness of the clasts is indicative of long distance transportation before deposition. The uniformity of the mineralogical composition of the clast, being made up of quartz/quartzite, supports that derivation from vein quartz and/or quartzite. The normal graded conglomerate suggests deposition by current possibly by longitudinal gravelly bars and lag deposits in a braided fluvial setting. The conglomerate probably indicates sedimentation in high energy bedload braided streams [22] [23]. The thin layer of ferruginised sandstone characterised by polygonal cracks (mud cracks) and erosional surface probably represents lowering of the base level which must have led to subaerial exposure and subsequent erosion.

The layer of the diamictite usually composed of elongate to rounded boulders in sandy matrix, could be interpreted as debris flow deposit. The upper and lower thin layers made up of boulders of pre-existing sedimentary rock. Admixture of clasts derived from diverse sediment sources-mudstone, siltstone, sandstone and ferruginised conglomerate is a diagnostic evidence of reworked deposits. The sharp continuous contact in the debris flows deposit suggests deposition at different times. These debris flow deposits were probably transported by vigorous floodwater for a relatively variable distance before deposition. The well rounded granules to pebbles probably traveled long distance when compared with the large boulders. The abundant sand matrix, absence of sorting and disorganized fabric of the debris deposit suggests rapid deposition due to a catastrophic flood event. Massive sands without associated current related sedimentary structures are interpreted as deposit of gravity flow processes.

\subsubsection{Oke Osho Location}

Two main sand mining sites were visited in Oke Osho, one is located on the main road along Epe-Itoikin road with coordinates $\mathrm{N}-06^{\circ} 36.811^{\prime}$; E- $003^{\circ} 56.267^{\prime}$ and the second is located away from the main road with the coordinate $\mathrm{N}-06^{\circ} 36.769$ '; $\mathrm{E}-003^{\circ} 55.793$ '. In these two sand mining sites five types of lithofacies were studied. They are laminated siltstone, clay, coarse grained sandstone, debris flow deposits and normal graded sand (Figure 7 and Figure 8).

Very fine grained sand/siltstone: This facies was identified at the sand mining site located along Epe-Itoikin road. Field experience shows that it is the lowest lithologic unit that was recognised, although not well exposed in the sedimentary section in the quarry. It is horizontally bedded, milky white and brown to light brown. The sand grains are angular to subangular, subdiscoidal to discoidal and moderately sorted. It is friable, non-sticky and non-kaolinitic. Both mica flakes and carbonaceous detritus are present. Quartz makes up about 98\%, mica $1 \%$, carbonaceous detritus $1 \%$ of this lithofacies. The lithofacies exhibits horizontal lamination and individual laminae show alternation of white and brown colours. The lower section of the facies is not exposed but the upper contact is sharp with the overlying clay. The exposed section of the lithofacies that was logged varies from $3.2 \mathrm{~m}$ to $60 \mathrm{~cm}$. The lithology log showing the lithofacies and overlying lithology is shown in Figure 11 where it occurs as the lowest unit.

Clay: Clay lithofacies in this mining site was exposed in all the major sedimentary successions. It is predominantly white, variegated and contain colours like yellow to brown-yellow and reddish brown. The lower boun- 
dary is characterised by sharp contacts at the upper and lower boundaries. Field experience shows that this lithofacies exhibit wedge geometry as it thins towards the south-east and thickens towards the northwest (Figure 8).

Coarse grained sandstone: It is composed of medium to coarse grained sand. Its colour is light brown to dark brown. The sands are angular to subrounded, subdiscoidal to discoidal and poorly sorted. The thickness of the lithofacies varies from $70 \mathrm{~cm}$ to $2.4 \mathrm{~m}$. The upper boundary exhibits distinct erosional surface which some trace fossils (ichnofossils) are present. Sedimentary structures are not readily observed in the lithofacies. Essentially, this lithofacies is dominated with quartz grains (95\%), although accessory minerals such as micas and other clayey materials (Figure 7 and Figure 8).

Debris Flow Deposit (Diamictite?): The diamictite observed at Oke Osho is not exactly same as the one studied along Igbonla road in terms of compositional characteristics. In the sedimentary successions exposed at Oke osho the boulders of ferruginised sandstone are not confined to particular layers, instead they are well distributed in the lithofacies. It exhibits sharp contacts with the underlying and overlying lithofacies. The lithofacies occurs as a poorly sorted conglomerate of assorted rock fragments-ferruginised mudstone, siltstone and sandstone. The clasts are predominantly boulder in sized in the sand mining site located near the major road. These textural characteristics changes to granule and pebble sizes at the second mining site located away from the main road. Well rounded cobbles of pre-existing rocks were observed. Rock fragments are in various shapes - rounded, subrounded and elongate. Elongate boulders exhibit various forms of arrangement, from inclined to slightly inclined and horizontal. The thickness of the lithofacies is between $60 \mathrm{~cm}$ and $4.2 \mathrm{~m}$ (Figure 7 and Figure 8).

Normal Graded Sand: This lithofacies is composed of light brown clayey sand. Clayey materials serve as weak coating on the quartz grains. Quartz grains are fine to coarse, subangular to subrounded, subdiscoidal to spherical and poorly sorted. Weathering has adversely affected the exposed surface and it is mottled. Sedimentary structures are not recognized, probably as a result of the weathering. The lithofacies was identified in Oke

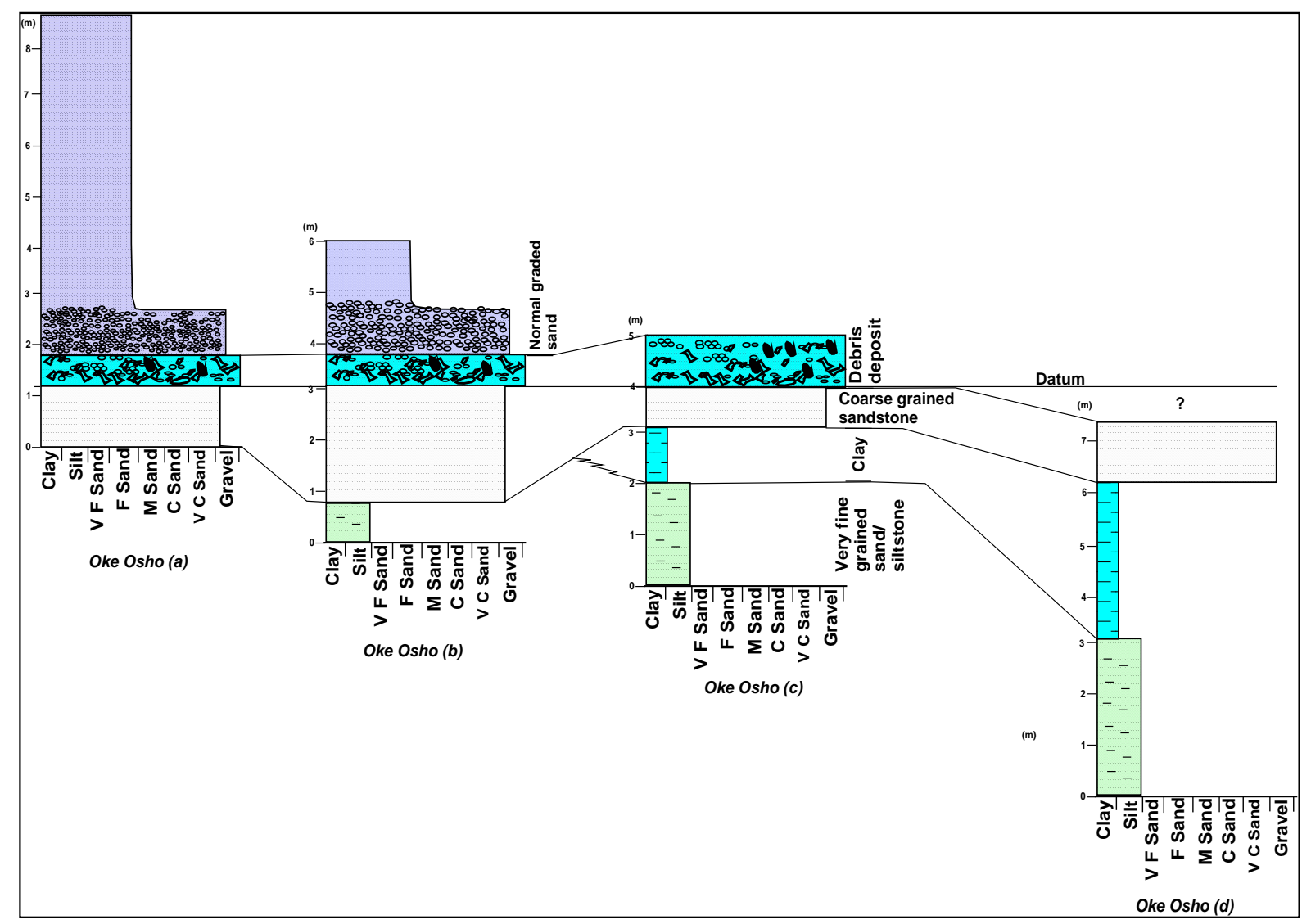

Figure 7. Lithology logs and lithofacies correlation at Oke Osho (mining site along the highway). 


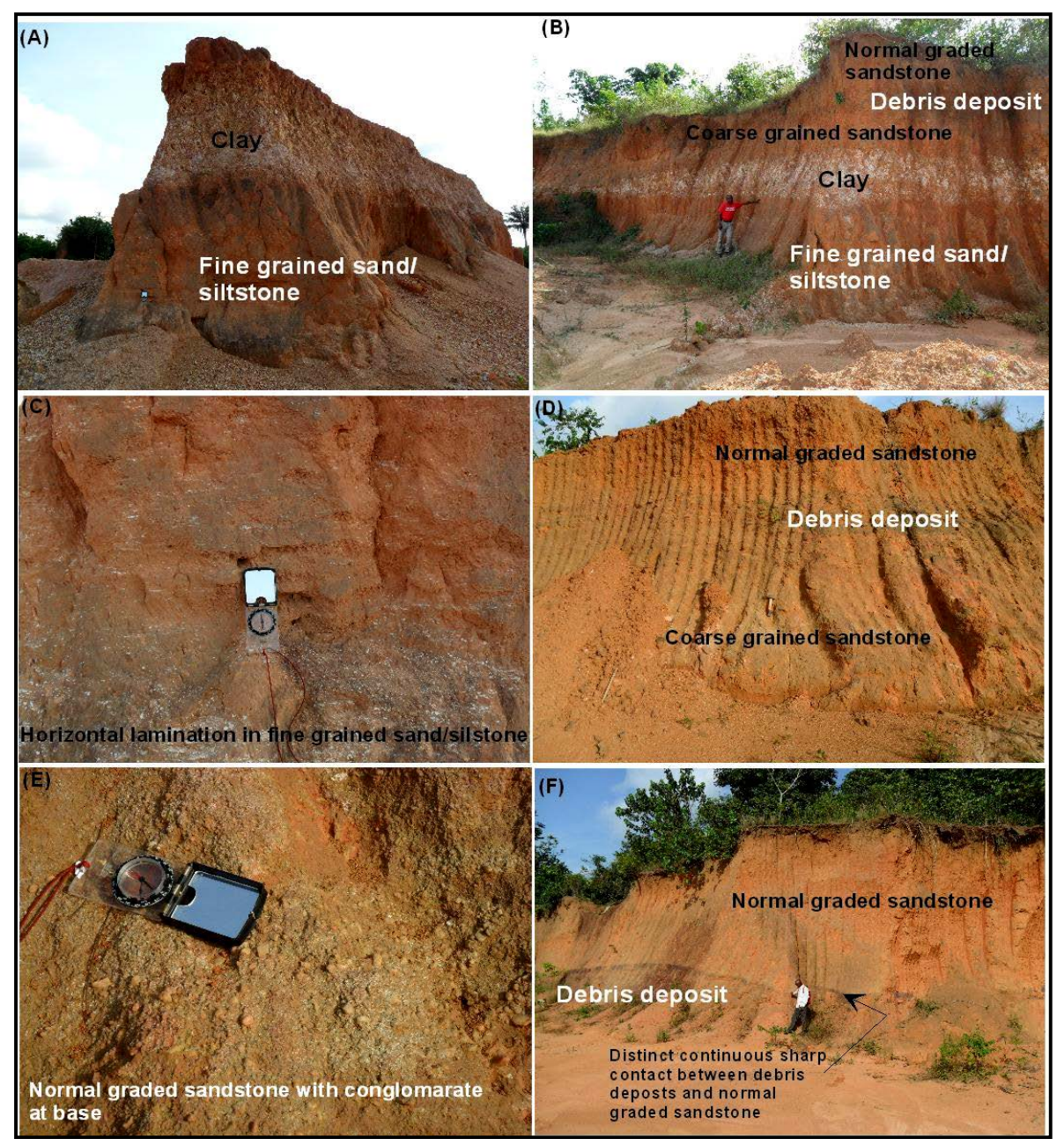

Figure 8. Field photographs of lithofacies studied at Oke Osho.

Osho mining sites as upward fining sand. The lower section is conglomeratic and composed of quartz pebbles intimately arranged in clayey sand matrix (Figure 7 and Figure 8).

Interpretation: The different units that were identified grade vertically into one another either with or without gradation or sharp contact. The fine to coarse grained nature of the sand and near-constant direction of paleocurrent all suggests deposition by fluvial currents. The occurrence of horizontal bedding beddings indicates evidence of deposition by current. The lithofacies is interpreted as deposits of linguoid, transverse bars and sand waves in the lower flow regime. [23] interpreted similar planar cross bedded sands as sandy bedforms that developed as a result of sand migration under lower flow regime conditions in low sinuosity braided stream. Therefore, the characteristic of the planar bedded fine grained sand marks the lower flow regime and the sand deposition occurred under shallow water conditions. The horizontal laminations could have resulted from deposition of suspended sediments. The clay units within the lithofacies are interpreted as clay plugs filling abandoned channels or as overbank clays. This type of lithologic associations is consistent with meandering or braided river styles [18]. The geometry of the clay deposits suggest abandoned channels sedimentation. The horizontal lamination is a key characteristic of deposition from suspended sediments. This probably resulted from extremely coarse grains of sediments deposited as traction loads during the waning of water current. This agrees with interpretation of the workers who explained that massive or crudely bedded coarse sand characterised by horizontal bedding were products of longitudinal bars, lag deposits and sieve deposits [18] [19] [24]. The coarse grained section suggests deposition by turbulent flows and as the energy of deposition decreases the finer grain section of the sediments is deposited. The same interpretation of debris flow deposits as observed in Igbonla traverse is also applicable to the same layer in Oke Osho. 


\subsubsection{Ketu Location}

The sand mining site located in Ketu is along the main road to Itoikin at the current position where power station is being built. The coordinate is $\mathrm{N}-06^{\circ} 37.909$ '; $\mathrm{E}-003^{\circ} 53.474$ '. In the sand mining site four types of lithofacies were recognised. They are clay, tabular cross bedded very coarse grained sandstone, horizontal bedded coarse grained sandstone, inversely graded sandstone and massive sand (Figure 9 and Figure 10).

Clay: Clay lithofacies is exposed in the major sedimentary successions. It is predominantly white, but it has been stained with other colours probably as result of weathering. These colours are yellow, brown and reddish-brown. The lower boundary and upper boundaries are characterised by sharp contacts. Field experience shows that this lithofacies exhibit variation in its thickness from $20 \mathrm{~cm}$ to $1.8 \mathrm{~m}$.

Tabular Cross Bedded Very Coarse Grained Sandstone (Iron rich): The lithofacies is made up of very coarse grained sandstone, which are divisible into iron rich and non iron rich layers. The iron rich interval was recognised at two stratigraphic intervals separated by clay lithofacies. They exhibit black to dark brown with occasional ox-blood to red colours at the top of the cross beds. The sandstones are angular to subangular and poorly sorted. The lower boundary of the layer below was not exposed in the outcrops, but the upper boundary is characterised by sharp contact. The upper layer is characterised by sharp contact in the lower boundary and transitional contact with overlying lithofacies. The thickness of the lithofacies varies from $70 \mathrm{~cm}$ to $2.4 \mathrm{~m}$. Tabular cross bedding sedimentary structure is present in these two layers. In one of the exposures this sedimentary structure forms angular termination with the lithology above.
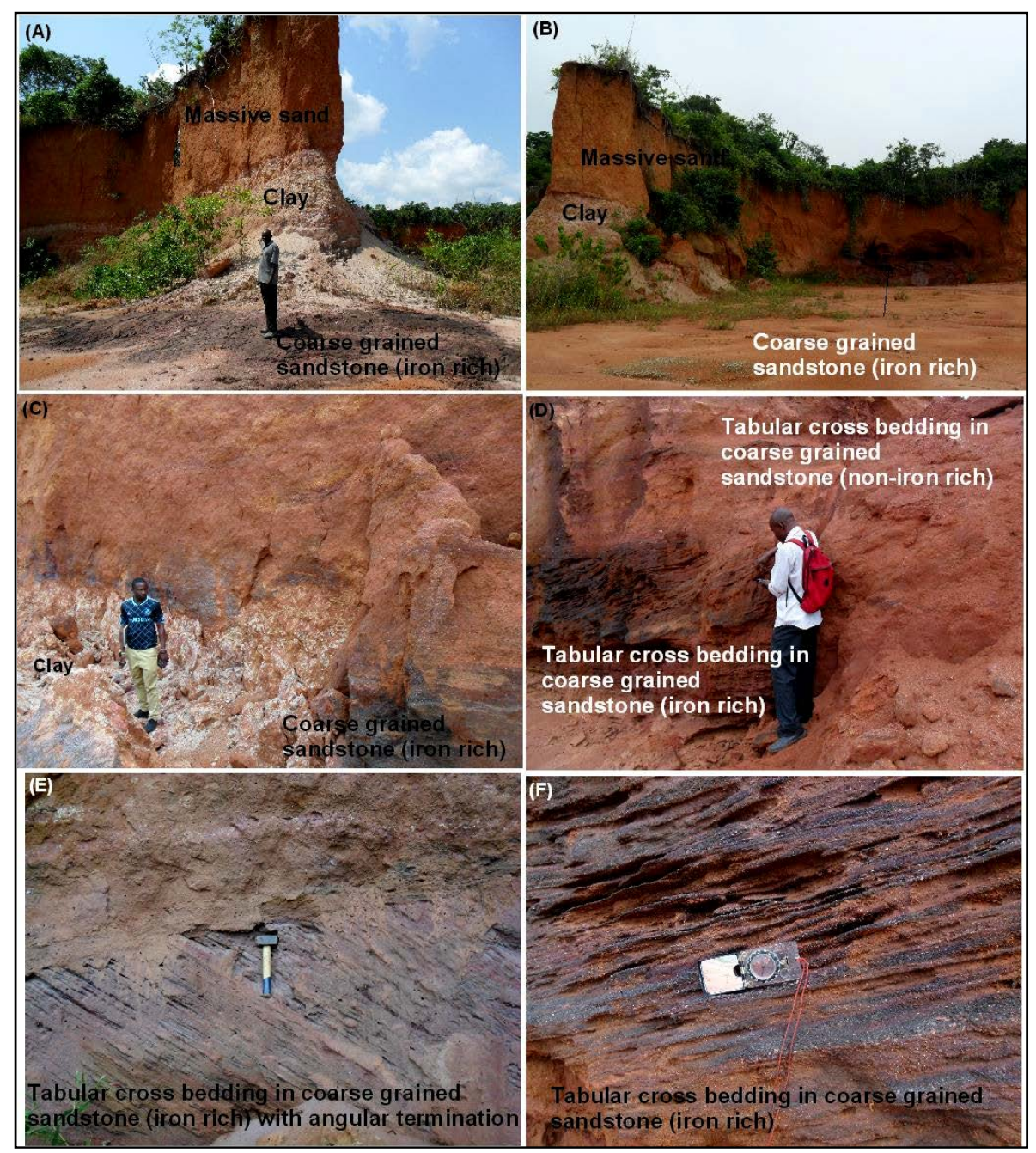

Figure 9. Field photographs of lithofacies studied at Ketu. Note the overbank clays and the sedimentary ironstone. 


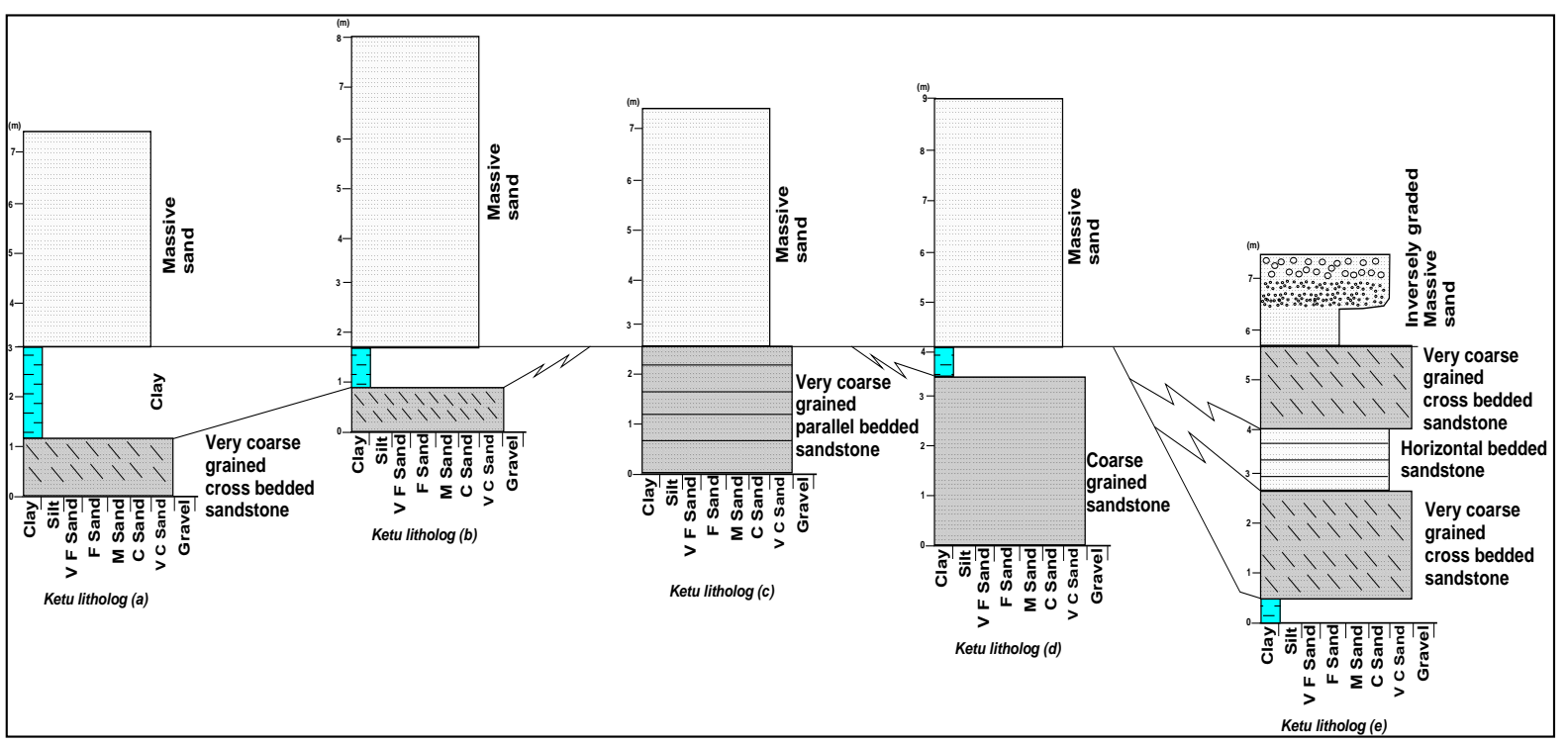

Figure 10. Lithofacies and correlation in Ketu exposure.

Generally, the lithofacies are highly indurated with occasional layers that are unconsolidated. Paleocurrent measurement is generally in the southwest direction and the values vary between $228^{\circ}$ and $238^{\circ}$ (Figure 9). The degree of induration of this lithofacies is variable while some sections of the exposure is highly indurated the other section with angular termination is unconsolidated.

Tabular Cross Bedded Very Coarse Grained Sandstone (Non iron rich): This lithofacies is similar in textural characteristics with the iron rich layer. It occurs at the upper of the iron rich layer, its colour is predominantly brown with few patches of black colouration and less indurated.

Horizontally Bedded Coarse Grained Sandstone: This lithofacies displays horizontal beds that are composed of coarse grained sandstone. The grains are sub-angular to angular with few that are sub-rounded. Its colour is variable consisting of brown, red and deep yellow, pebbly, very coarse and poorly sorted. It is arranged into beds of $3-7 \mathrm{~cm}$ thick. Within these beds minor cross bedding structure is present. This lithofacies is matrix supported with poor tangential contacts among the clasts.

Massive to Inversely Graded Sand: The lithofacies occurs as the topmost unit as observed in this location. It is separated by distinct sharp boundary from the lithofacies that occur below it. In most of the exposed sedimentary successions at this location it is massive, but in one, inverse grading was observed (Figure 9). The colour is predominantly brown with few black patches. It is poorly sorted containing few pebbles to granules of quartz. The upper part is conglomeratic.

Interpretation: The relationship between the lithofacies supports fluvial sedimentation in continental environment. Planar to horizontal bedded coarse grained sandstone were likely to have been deposited by fluvial processes. The clay lithofacies with variable thickness and total disappearance in some sedimentary successions suggest sedimentation in abandoned channel. While the very thin parts in the clay is probably crevasse splay sediments. The presence of sharp contacts between the clay and other lithologies is an indication of fluvial channel erosional features. Occurrence of clay lithofacies at different intervals in the exposure represent cycles of sedimentation. Similar sandstone and clay bodies with cycles of sedimentation have been interpreted as fluvial deposits [20]. One of the diagnostic distinguishing features of fluvial sediments is the occurrence of cross bedded coarse grained sediments in association with climbing ripple lamination and structures indicative of sedimentation by levee and crevasse splay deposits.

\subsubsection{Caleb University Road Cut}

Road cut outcrops occur near the main gate of Caleb University along the way to Ikorodu. The GPS location at this point has the following coordinate $\mathrm{N}-06^{\circ} 39.979^{\prime} ; \mathrm{E}-003^{\circ} 38.392^{\prime}$. The road cut is extensive for a distance of over $100 \mathrm{~m}$ but thick vegetation has covered part of the exposure. In the exposure four types of lithofacies recognised are medium to coarse grained sandstone, clay, debris deposit and massive sand (Figure 11). 

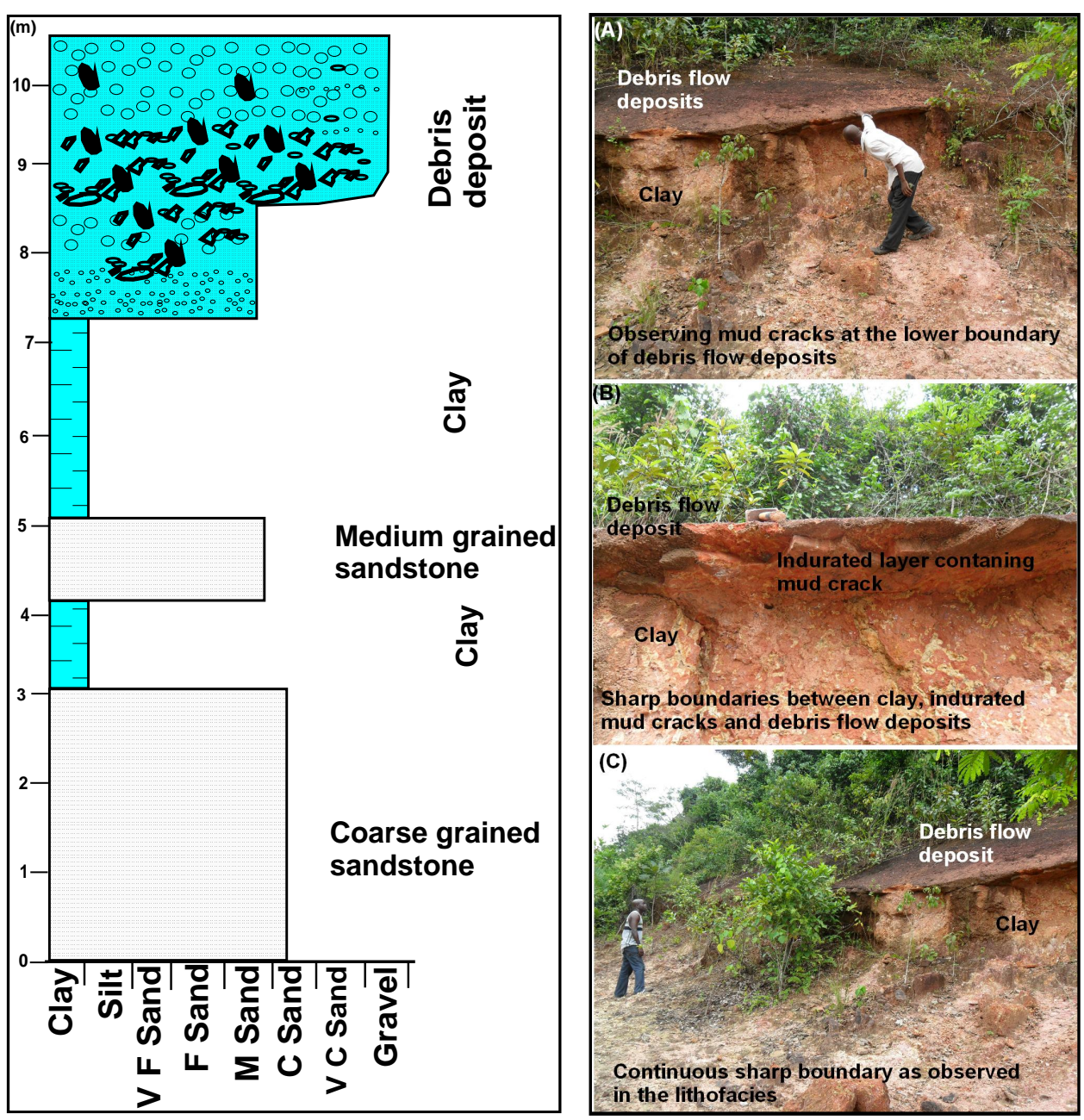

Figure 11. Combination of lithology log and field photographs of lithofacies recognised near Caleb University. (A) and (C) show the field geologists observing primary sedimentary structure (mud cracks).

Medium to Coarse Grained Sandstone: The section that was studied is made up beds of medium to coarse grained sandstone separated by clay beds. Its colour is variable, from brown to milky white. The sands are angular to subrounded, subdiscoidal to discoidal and moderately sorted. The thickness of the lower bed is approximately $3.1 \mathrm{~m}$ while the upper one is $60 \mathrm{~cm}$. The upper bed has higher clay content compared to the one below. Essentially, this lithofacies is dominated with quartz grains, although accessory minerals such as micas are present.

Clay: The clay lithofacies occurs at two different intervals with the thicknesses of $1.1 \mathrm{~m}$ and $2.3 \mathrm{~m}$ for lower and upper beds respectively. It is white in colour and mottled. This has caused the introduction of other colours such as yellow, brown and red. The lower boundary of the two beds are characterised by gradational contacts. In the lower bed the upper boundary is gradational while in the upper bed the upper boundary is sharp, continuous and erosional. Field observation shows that the exposed surface of this upper boundary is characterized by mud cracks.

Debris Flow Deposit: Debris flow deposit was recognised at the upper part of the exposure. It exhibits a sharp but irregular and continous contact with the lower and upper beds. The lower part is separated from the underlying clay by $3 \mathrm{~cm} \mathrm{-} 7 \mathrm{~cm}$ thick of indurated sandstone. It is brownish to blackish in colour and composed of poorly sorted, medium to very coarse quartz grains. The clasts are composed of mudstone, siltstone and sandstone of various sizes varying from granules to cobbles. Quartz grains of the matrix are angular to subangular, and subdiscoidal to discoidal. The thickness of the layer is approximately $3.1 \mathrm{~m}$ (Figure 11). 
Massive Sand: This lithofacies occur as the topmost unit at the exposure. The textural features of the lithofacies are similar to those that have been described.

Interpretation: The lithofacies successions recognised from alternating beds of clay and medium to coarse grained sandstone below, through debris flow deposits and capped by massive sand suggest upward regressive deposition in continental environments. These lithofacies are interpreted as products of fluvial deposition. This is based upon the textural characteristics and lithological associations of the lithofacies.

This interpretation is further supported by the occurrence of erosional surfaces and mud cracks, which is an indication of exposure after the deposition of the upper clay lithofacies. The clay and sandstone lithofacies are interpreted as deposition in active and abandoned channels respectively. The clay lithofacies were deposited as plugs filling in abandoned channels or as overbank clays. This type of lithologic associations is consistent with meandering or braided river styles [18]. This interpretation agrees with the work of [25] and Roberts [19].

Debris flow deposits separated from the underlying layer by continuous erosional surface and thin layer of sandstone is indicate a period of break in sedimentation and exposure. The sharp continuous contact in the debris flows deposit suggests deposition at different times. These debris flow deposits were probably transported by vigorous floodwater as was previously mentioned for other locations where the lithofacies has been recognised.

\subsubsection{Isheri-Magodo Exposure}

Isheri-Magodo sedimentary exposure is located in a well built up area in Lagos with the following coordinate $\mathrm{N}-06^{\circ} 38.304^{\prime} ; \mathrm{E}-003^{\circ} 28.487^{\prime}$. The sedimentary successions were exposed as a result of gully erosion that has affected the area. Three lithofacies recognised are silty clay, laminated clay and clayey sand (Figure 12).

Silty Clay: The silty clay lithofacies occurs as the lowest unit that was exposed. The background colour of the lithofacies is milky white to light gray in association with other colours like light yellow and light brown. These colours occur as band within the background colour. It is fairly gritty, slightly slippery and massive. The contact between the lithofacies and the overlying one is gradational and subtle. The thickness of this lithofacies as exposed on the road sections is variable, but range from $1.7 \mathrm{~m}$ to $2.1 \mathrm{~m}$.

Shale: The shale unit as observed in this exposure is composed of alternation of milky white, light brown and dirty yellow colours. It is slippery, smooth and flaggy. The exposed sections are papery as a result of the fissility. The thickness of this lithofacies is variable, essentially it ranges from $1.8 \mathrm{~m}$ to $2.3 \mathrm{~m}$.
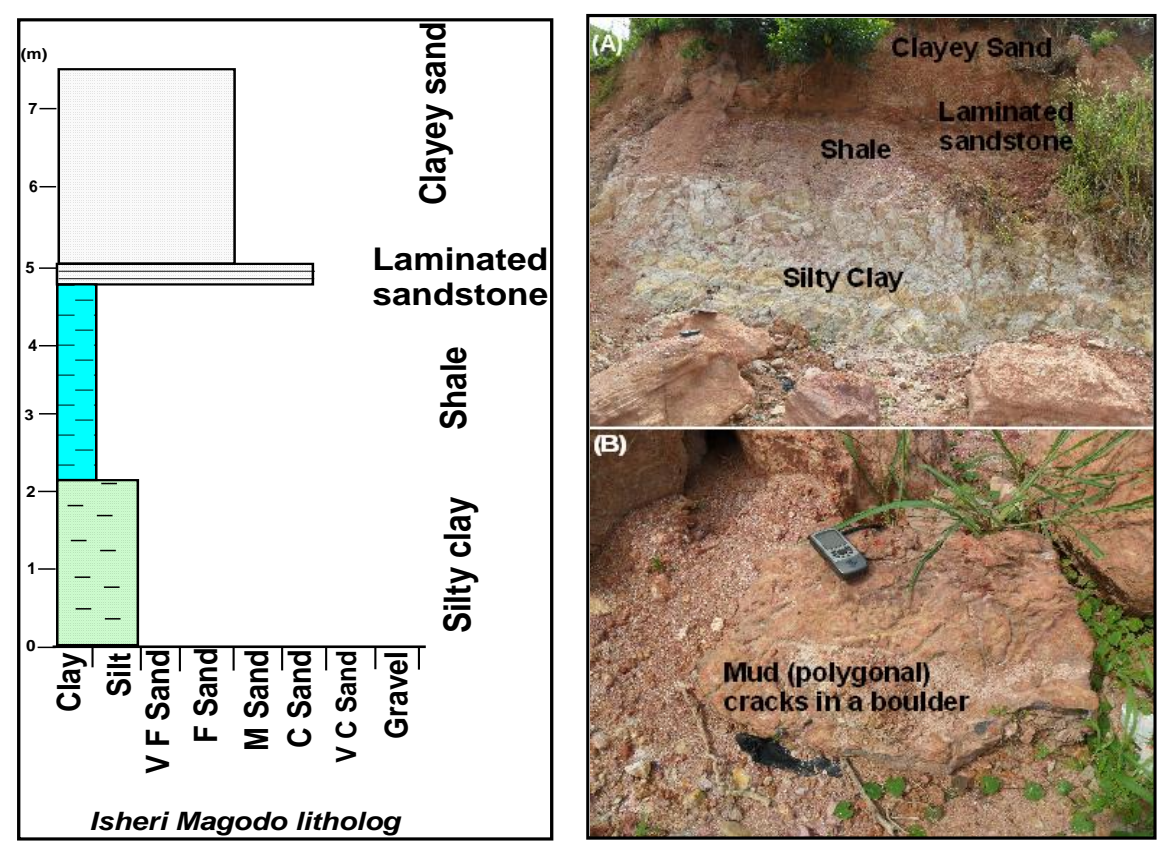

Figure 12. Combination of lithology log and field photographs of lithofacies recognised at Isheri Magodo. Primary sedimentary structure (mud cracks) was also recognised at this location. 
Laminated Sandstone: The lithofacies occurs as well laminated layer of sandstone less than $1 \mathrm{~m}$ in thickness. It is predominantly black with bands of yellow, brown and reddish colours. These bands occur as laminae within the lithofacies. This lithofacies displays horizontal beds that is made up of coarse quartz grains, angular to sub-angular and poorly sorted. A boulder exposing the base of the lithofacies shows the occurrence of mud (polygonal) cracks (Figure 12). It exhibits variable depositional contacts with the lithofacies below and above it. In some of the exposure it is gradational, while in others it is sharp.

Clayey Sandstone: This lithofacies occur as the topmost unit and overlies the shale. It is reddish brown with specks of dull white colour. The upper section is not exposed, but the lower contact with the underlying indurated sandstone is variable; gradational in some parts and sharp in others. It is compose of medium to coarse quartz grains, sub-angular to sub rounded and poorly sorted Thickness measured on the outcrop is between 1.3 $\mathrm{m}$ and $2.6 \mathrm{~m}$.

Interpretation: The deposition of clay units have been related to weak transporting currents, where accumulation of fine grained materials can take place under quite water conditions (Prothero and Schwab, 1996). These are very fine grained siliciclastics that settle out of suspension. Horizontal lamination is a key characteristic of deposition from suspended sediments, which is interpreted as product of overbank deposits in fluvial environment. This probably resulted in the deposition of the shale or laminated mudstone. The occurrence of thin layer of indurated sandstone characterised by mud cracks is an indication of exposure surface after the deposition of the shale. The indurated sandstone characterized by horizontal lamination is rich in iron. The stratification of iron enrichment layer with other lithology may be interpreted as product of surficial process before the deposition of the overlying lithology.

\section{Sequence Stratigraphic Architecture}

Major exposures in the area of study were correlated using sequence stratigraphic approach in order to have a better understanding of the facies development. The correlation turned out being relied upon using more of lithological criteria. The observations made during fieldwork suggest that good exposures, facies affinities, facies dislocations and sequential trends are extensive enough to allow reliable correlation. Figure 13 illustrates the stratigraphic and sequential architecture of the major exposures that were studied during the fieldwork. These exposures cover the stretch between Igbonla through Oke Osho, Ketu, Ikorodu and Magodo. With respect to the differential facies boundaries and dislocations, depositional sequences (DS) of the lithologies in the area are defined on the basis of transgressive - regressive cycles and are bounded by major sequence boundaries. But all the depositional sequences (DS) recognised are incomplete, this may be attributed to high level of erosion, sediment bypass and continental nature of the sediments in the area. Fluvial scale aggradational cycles are grouped into four depositional sequences on the basis of an overall upward trend of decreasing or increasing grain sizes, the presence of erosional bounding surfaces and facies dislocations. On the basis of the above criteria three sequence boundaries (SB II - SB IV), systems tracts (LST, TST, HST) and four depositional sequences (DS I to DS IV) were recognised. SB I which supposed to represent the sequence boundary of DS I was not exposed in all the studied sedimentary exposures.

Depositional Sequence I (DS I): DS I consists of a complete transgressive-regressive cycle made up of lowstand, transgressive and highstand systems tracts. Although all the systems tracts could not be identified in all the locations, but the correlation of the lithofacies enabled the sequential order of the systems tracts and their vertical arrangement (Figure 13, Figure 14 and Figure 15). In the Igbonla traverse DS I was dominated by TST, which was recognised in many of the exposures. Similarly the HST was equally exposed, unlike the TST, the HST was poorly preserved as result it was not recognised in many of the exposures. The LST of DS I is the most prominent and was identified in all the exposures except at Igbonla traverse. The lower sequence boundary was not recognised in any of the exposures visited. Sequence Boundary II (SB II) is an intraformational composite erosional surface that merged with SB III along the line of correlation in the approximate west-east direction. This erosional surface exhibits primary sedimentary structure (polygonal/mud cracks), which confirm the exposure of this surface in the geologic past. Polygonal cracks, which suggest subaerial exposures, were clearly identified in two locations at Mafo and Caleb University. This is an indication of lowering of sea level.

Depositional Sequence II (DS II): Sediments of DS II were only preserved at Igbonla traverse where they occur as normal graded, oligomict para-conglomerate with occasional ferruginised lower surface (SB II). As a result of the nature of the surfaces associated with the sediments it was interpreted as lowstand deposits of DS II. 


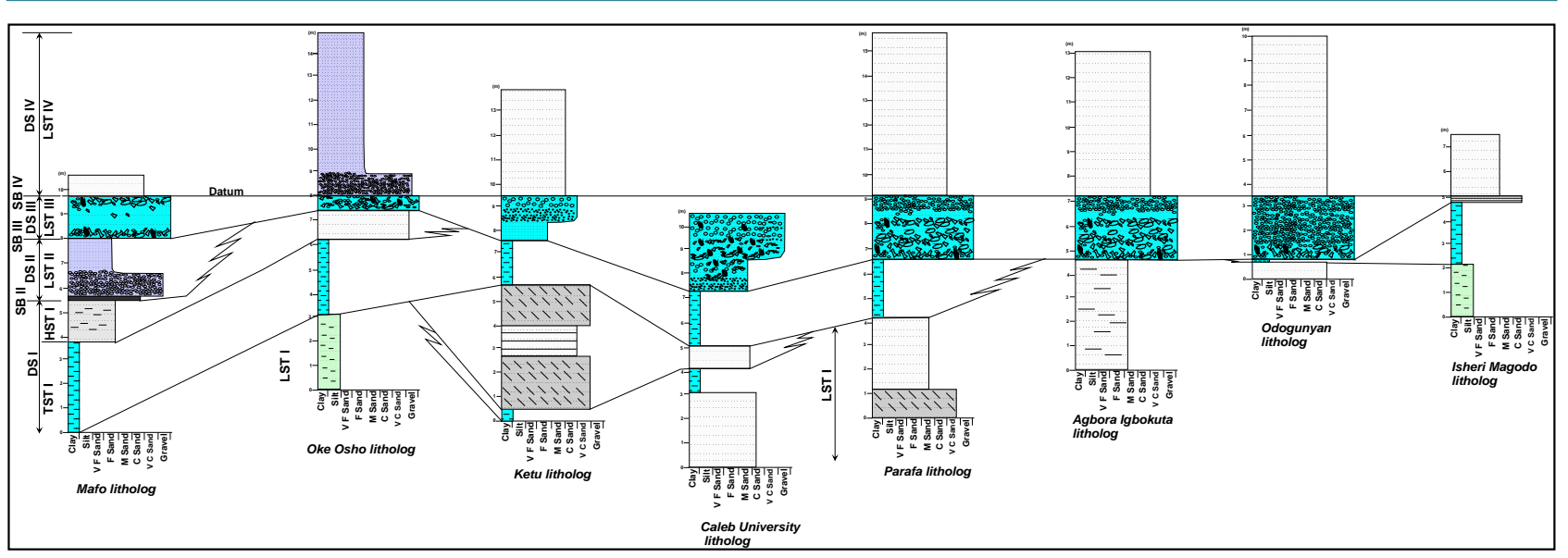

Figure 13. Correlation of major exposures in the Lagos East Senatorial District using sequence stratigraphic approach. DS-depositional sequence, SB — sequence boundary, TST — transgressive system tracts, HST—highstand system tracts, LST—lowstand system tracts.

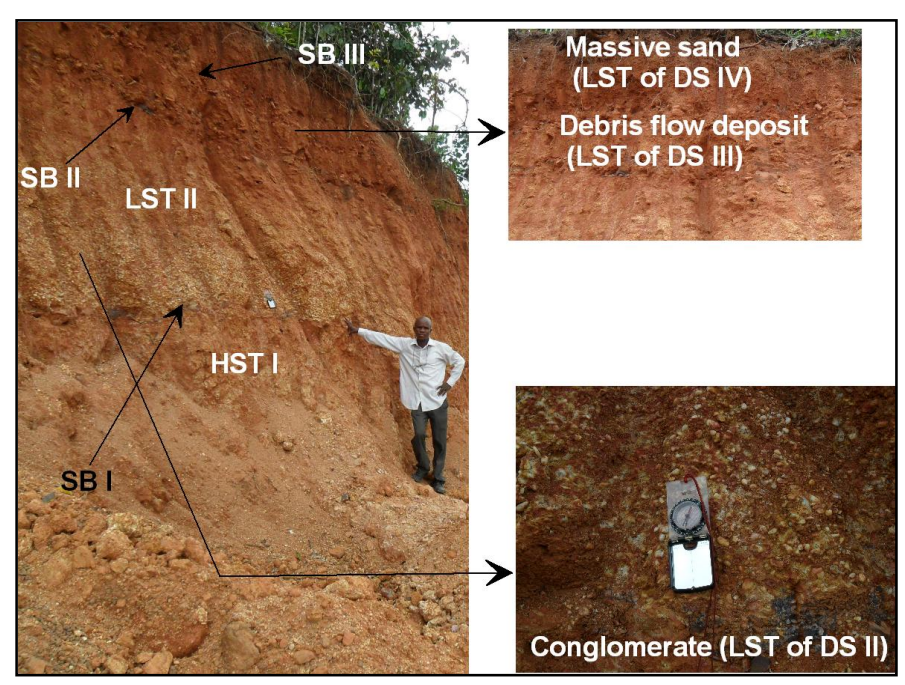

Figure 14. Field photographs of sequence stratigraphic elements in depositional sequences I, II and III.

Non preservation of the sediments in most of the exposures may be attributed to high level of erosion or sediment bypass.

Depositional Sequence III and IV (DS III and DS IV): The overlying debris flow deposit was recognised in all the exposures where it forms a sharp boundary with the lithofacies below and above it. These sharp boundaries were interpreted as SB III and SB IV. The debris flow deposit was interpreted as LST of depositional sequence III. DS III is purely a regressive and incomplete sequence characterised by the absence of TST and HST. In one of the exposures SB III exhibited the occurrence of polygonal/mud cracks, which confirm the exposure of this surface. The topmost massive unconsolidated sandstone layer recognised in all the exposures was recognised as the LST of DS IV (Figure 13, Figure 14 and Figure 15).

\section{Discussion}

\section{Re-Interpretation of Tertiary Sedimentary Successions}

The Tertiary sedimentary successions recognised in the present study are predominantly continental sediments deposited in varied continental environments. The nature of the surfaces identified in the sediments suggested that they have eroded, exposed and primary sedimentary structure has developed. Although some attempts have 


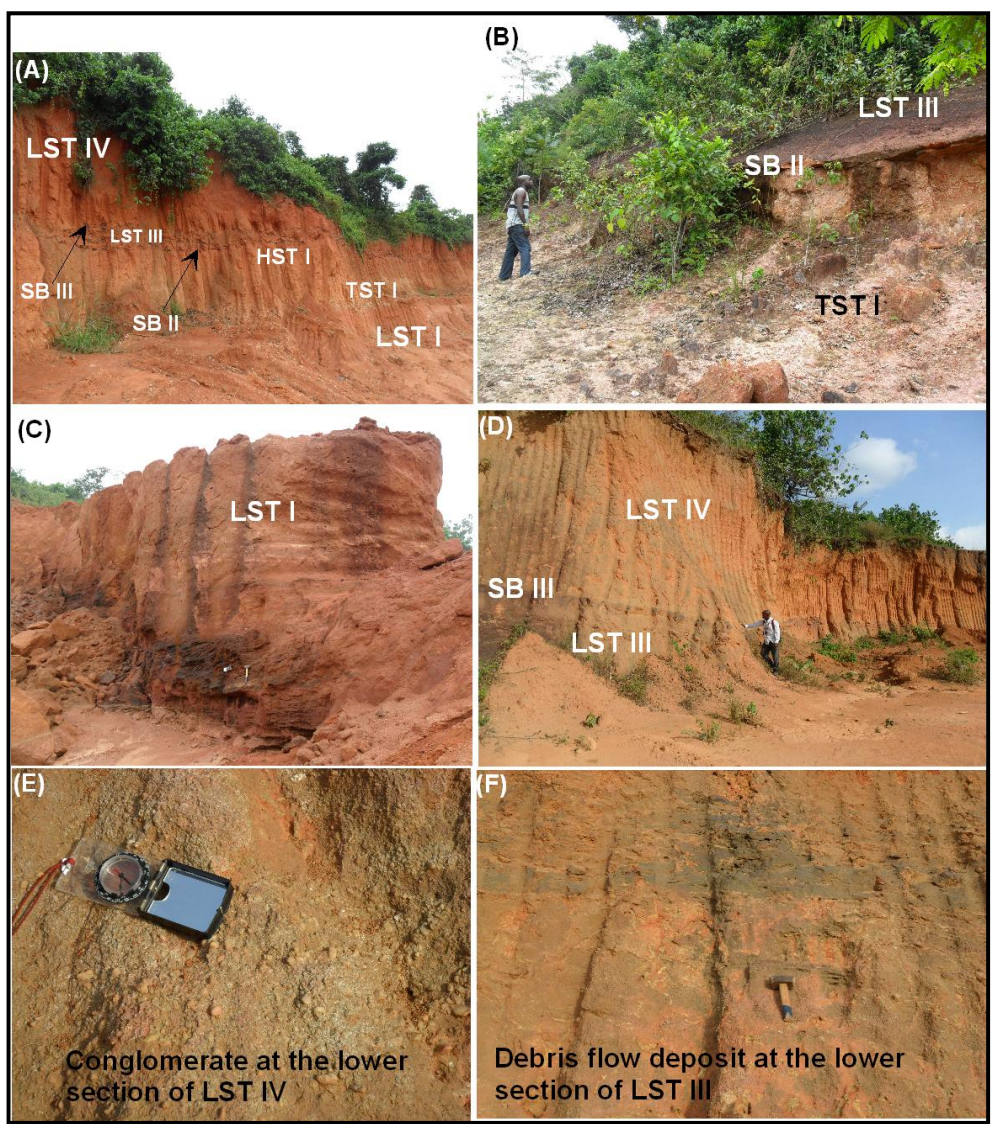

Figure 15. Field photographs of sequence stratigraphic elements in the depositional sequences.

been made by some workers to study the Nigerian sector of the Dahomey Basin, the basin particularly the onshore and offshore portion is still little understood in terms of it lithostratigraphic subdivision, tectonics and mineral resources. This may not be unconnected to limited research work that has been carried out on the basin, and paucity of data that have been acquired both in the onshore and offshore parts. The lithostratigraphic units in the Dahomey Basin have been described variously, probably due to limited borehole coverage and non-availability of enough outcrops for detailed stratigraphic studies. Other explanations are due to missing units attributed to series of erosion and/or unconformity already identified in the area [26] [27]. The stratigraphy of the sediments in the Dahomey Basin is controversial.

The only existing geological map on the basin produced by [1] has recognised the exposed sedimentary successions in the area of study as Coastal Plain Sands/Benin Formation and Alluvium, which consist of littoral and lagoonal deposits. The present fieldwork carried out in the area has revealed that the outcrops of sedimentary successions contain lithofacies that can be regarded as part of Ilaro Formation. As previously described Ilaro Formation is a sequence of predominantly coarse sandy estuarine, deltaic continental beds which display lateral facies changes [28]. It consists of coarse, angular and poorly sorted sand with considerable amount of clay layers and rare occurrence of shale. The environment of deposition varies from marine to non-marine deposits exhibiting transition from marine in the basal part to continental in the upper beds. Over most of the outcrops, the formation is continental in character and shows lateral changes in thickness and lithology which are rapid and confusing. The sediments identified in the present study area have confirmed the continental character and lateral changes in facies of the Ilaro Formation.

The Coastal Plain Sands consist of soft, very poorly sorted, clayey sands, pebbly sands, sandy clay and rare thin lignites. It is made up of yellow and white, sometimes cross-bedded sand and clays. They are hardly distinguished in the field from much of the Ilaro Formation as a result of lithological similarity [1]. It has also been revealed in the cause of this fieldwork, the Ilaro Formation has different lithofacies, which are easily distin- 
guished on the field based on their lithic characters. They can be correlated from outcrop to outcrop and because of their lateral extension they can be sub-divided to members. Examples of these lithofacies are coarse grained sand and debris flow deposits, as shown in the field photographs and lithologic sections. Although it is hard to distinguish Ilaro Formation and Coastal Plain Sands/Benin formation in the field, where the exposure is good enough differentiation between the two formations can be carried out. The experience gathered from this fieldwork revealed that the possible boundary in the two formations occurs at the top of the debris flow deposits characterise by erosional and exposure features. The field studies of the lithofacies have shown that the sedimentary successions are predominantly of Ilaro Formation with fewer occurrences of Coastal Plain sands.

\section{Conclusions}

Emphasis on outcrop studies and recognition of facies has allowed the identification of continental sediments deposited in different depositional environments. The lithofacies indentified are: debris flow deposits, conglomerates, very coarse grained sand, ferruginous cross bedded sandstone, siltstone, shale/clay and massive sand. These lithofacies were interpreted as fluvial sedimentation characterized by abandoned channels and subaerial exposure.

Sequence stratigraphic surface well pronounced on the exposures is the sequence boundary. It is characterized by distinct facies dislocations and subaerial exposure features such as polygonal/mud cracks and thin bands of iron enrichment. Other surfaces were assigned based on the change in the lithofacies characteristics. The lithofacies recognised in the exposures were linked with four depositional sequences (DS I to DS IV). Only one of the depositional sequence (DS I) exhibited a complete regressive-transgressive cycle comprising LST, TST and HST, although the SB of this depositional sequence was not identified in the exposures. DS II was only recognised in one exposure where it exhibited a unique feature of normal graded oligomict para-conglomerate and interpreted as LST deposits. DS III and DS IV also showed similar feature to DS II of one lithofacies bounded at lower and upper parts by sharp boundaries. But in this case, the lithofacies were identified in several exposures and could be correlated.

On the basis of the facies and sequence stratigraphic elements identified, the sediments in this area are recognised as predominantly as part of the Ilaro Formation and fewer exposures as sediments of Coastal Plain Sands/ Benin Formation. Ilaro Formation recognised in the area of study has different lithofacies, which can be distinguished on the field based on their lithic characters. The lithofacies can be correlated on the outcrops as a result of their lateral extension and are divisible to members.

\section{Acknowledgements}

The authors sincerely expressed their warm gratitudes to members of staff of Lagos State Ministry of Energy and Mineral Resources and Seaseis Geophysical for their assistance and support during the fieldworks.

\section{References}

[1] Jones, H.A. and Hockey, R.D. (1964) The Geology of Part of Southwestern Nigeria Geol. Surv. Nigeria, Bull, 31, 101 p.

[2] Adegoke, O.S. (1969) Eocene Stratigraphy of Southern Nigeria. Collogue sur Eocene Vol. III Bur. Rech. Geol. Min. Mem., No. 69, 23-48.

[3] Brownfield, M.E. and Charpentier, R.R. (2006) Geology and Total Petroleum Systems of the Gulf of Guinea Province of West Africa U.S. Geological Survey Bulletin 2207-C.

[4] Reyment, R.A. (1965) Aspects of the geology of Nigeria-The Stratigraphy of the Cretaceous and Cenozoic Deposits. Ibadan University Press, 133 p.

[5] Omatsola, M.E. and Adegoke, O.S. (1981) Tectonic Evolution and Cretaceous Stratigraphy of the Dahomey Basin. Nigeria Journal Mining and Geology, 18, 130-137.

[6] Coker, S.J.L. and Ejedawe, J.E. (1987) Petroleum Prospect of the Benin Basin Nigeria. Jour. Min. and Geol., 23, 7-43.

[7] Coker, S.J.L. (2002) Field Excursion Guide to Tar Sand Outcrops in Benin Basin. NAPE Mini-Conference, 32 p.

[8] Billman, H.G. (1992) Offshore Stratigraphy and Eontology of Dahomey (Benin) Embayment. NAPE Bulletin, 70, 121-130.

[9] Haack, R.C., Sundararaman, P., Diedjomahor, J.O., Xiao, H., Gant, N.J., May, E.D. and Kelsch, K.(2000) Niger Delta 
Petroleum Systems, Nigeria. In: Mello, M.R. and Katz, B.J., Eds., Petroleum systems of South Atlantic Margins: AAPG Memoir 73, 213-231.

[10] Miall, A.D. (1978) Lithofacies Types and Vertical Profile Models in Braided River Deposits: A Summary. In: Miall, A.D., Ed., Fluvial Sedimentology, 597-604.

[11] Prothero, D.R. and Schwab, F. (1996) An Introduction to Sedimentary Rocks and Stratigraphy, Sedimentary Geology. W.H. Freeman and Company, New York, 575 p.

[12] Nwajide, C.S. and Reijers, T.J.A. (1996) Geology of the Southern Anambra Basin. In Selected Chapters on Geology; Sedimentary Geology and Sequence Stratigraphy in Nigeria and Three Case Studies and a Field Guide, 197 p.

[13] Haq, B., U. Hardenbol, J. and Vail, P. (1987) Chronology of Flunctuating Sea-Levels since the Triassic. Science, 235, 113-1165. http://dx.doi.org/10.1126/science.235.4793.1156

[14] Van Wagoner, J.C., Posamentier, H.W., Mitchum, R.M., Vail, P.R., Sarg, J.F., Loutit, T.S. and Hardenbol, J. (1988) An Overview of Sequence Stratigraphy and Key Definitions. In: Wilgus, C.K., Hastings, B.S., Kendall, C.G.St.C., Posamentier, H.W., Ross, C.A. and Van Wagoner, J.C., Eds., Sea Level Changes-An Integrated Approach, Vol. 42, SEPM Special Publication, 39-45. http://dx.doi.org/10.2110/pec.88.01.0039

[15] Van Wagoner, J.C., Mitchum, R. M., Campion K. M. and Rahmanian, V.D. (1990) Siliciclastic Sequence Stratigraphy in Well Logs, Cores, and Outcrops. American Association of Petroleum Geologists. Methods in Exploration Series, 7, $55 \mathrm{p}$.

[16] Catuneanu, O. (2002) Sequence Stratigraphy of Clastic Systems: Concepts, Merits, and Pitfalls. Journal of African Earth Sciences, 35, 1-43. http://dx.doi.org/10.1016/S0899-5362(02)00004-0

[17] Milton, N.J. and Emery, D. (1998) Outcrop and Well Data. In: Emery, D. and Myers, K.J., Eds., Sequence Stratigraphy, Blackwell Science Ltd., 61-79.

[18] Miall, A.D. (1996) The Geology of Fluvial Deposits. Springer-Verlag, Heidelberg. 582 p.

[19] Roberts, E.M. (2007) Facies Architecture and Depositional Environments of the Upper Cretaceous Kaiparowits Formation, Southern Utah. Sedimentary Geology, 197, 207-233. http://dx.doi.org/10.1016/j.sedgeo.2006.10.001

[20] Miall, A.D. (1985) Architectural-Element Analysis: A New Method of Facies Analysis Applied to Fluvial Deposits. Earth-Science Reviews, 22, 261-308. http://dx.doi.org/10.1016/0012-8252(85)90001-7

[21] Cantalamessa, G., Di Celma, C., Ragaini, L., Valleri, G. and Landini, W. (2007) Sedimentology and High-Resolution Sequence Stratigraphy of the Late Middle to Late Miocene Angostura Formation (Western Borbón Basin, Northwestern Ecuador). Journal of the Geological Society of London, 164, 653-665. http://dx.doi.org/10.1144/0016-76492006-001

[22] Ali Kalefa, E.M. (2005) Depositional Environments and Sequence Stratigraphy of Paralic Glacial, Paraglacial and Postglacial Upper Ordovician Siliciclastic Deposits in the Murzuq Basin, SW Libya. Sedimentary Geology, 177, 145-173. http://dx.doi.org/10.1016/j.sedgeo.2005.02.006

[23] El-Azabi, M.H. and El-Araby, A. (2005) Depositional Facies, Environments and Sequence Stratigraphic Interpretation of the Middle Triassic-Lower Cretaceous (pre-Late Albian) Succession in Arif El-Naga Anticline, Northeast Sinai, Egypt. Journal of African Earth Sciences, 41, 119-143. http://dx.doi.org/10.1016/j.jafrearsci.2005.02.005

[24] Cappuzo, N. and Wetzel, A. (2004) Facies and Basin Architecture of the Late Carboniferous Salvan-Dorénaz Continental Basin (Western Alps, Switzerland/France). Sedimentology, 51, 675-697. http://dx.doi.org/10.1111/j.1365-3091.2004.00642.x

[25] Martinsen, O., Ryseth, A., Hansen, W.H., Fleshe, H., Torkildsen, G. and Idil, S. (1999) Stratigraphic Base Level and Fluvial Architecture: Ericson Sandstone (Campanian), Rock Springs Uplift, SW Wyoming, USA. Sedimentology, 46, 235-259. http://dx.doi.org/10.1046/j.1365-3091.1999.00208.x

[26] Olabode, S.O. (2006) Siliciclastic Slope Deposits from the Cretaceous Abeokuta Group, Dahomey (Benin) Basin, Southwestern Nigeria. Journal of African Earth Sciences, 46, 187-200. http://dx.doi.org/10.1016/j.jafrearsci.2006.04.008

[27] Olabode, S.O. and Adekoya, J.A. (2008) Seismic Stratigraphy and Development of Avon Canyon in Benin (Dahomey) Basin, Southwestern Nigeria. Journal of African Earth Sciences, 50, 286-304. http://dx.doi.org/10.1016/j.jafrearsci.2007.10.002

[28] Kogbe, C.A. (1975) The Cretaceous and Paleogene Sediments of Southern Nigeria. In: Kogbe, C.A., Ed., Geology of Nigeria, Abiprint and pak Limited Ibadan, 436. 